DOI: $10.35643 /$ Info.26.1.9

Dossier temático: Ética de la Información

\title{
Information Ethics education in Southern Africa: A conceptual approach and curriculum model for university level instruction
}

\author{
Educación en ética de la información en África Austral: \\ Aproximación conceptual y modelo de currículum para la formación de nivel \\ universitario \\ Educação em Ética da Informação na África Austral: \\ Uma abordagem conceitual e modelo curricular para o ensino de nível \\ universitário
}

\author{
Coetzee Bester ${ }^{\mathrm{a}}$ \\ Johannes Britz \\ Bradley J. Wiles ${ }^{\mathrm{c}}$
}

\footnotetext{
${ }^{a}$ University of Pretoria Department of Information Science, School of Information Technology, IT Building 6-46.1, University of Pretoria, Private bag X20, Hatfield 0028, South Africa. ORCID: 0000-0003-0315-5860. Correo electrónico: coetzee@pamodzicc.co.za.

${ }^{\mathrm{b}}$ University of Wisconsin-Milwaukee School of Information Studies and University of Zululand, University of Wisconsin-Milwaukee, Office of the Provost and Vice Chancellor for Academic Affairs, Chapman Hall Room 215, 2310 E. Hartford Avenue, Milwaukee, Wisconsin, USA 53201. ORCID: 0000-0002-6651-9759. Correo electrónico: britz@uwm.edu.

${ }^{c}$ University of Wisconsin-Milwaukee School of Information Studies, NWQB Room 3550, 2025 E. Newport, Milwaukee, Wisconsin, USA 53201. ORCID: ㅁ000-0003-1592-7119. Correo electrónico: bjwiles@uwm.edu.
}

\begin{abstract}
This article proposes the Information Ethics Curriculum Model, a university-level educational heuristic aimed at promoting safe, responsible, and advantageous information use in multicultural settings across Southern Africa. The Model is designed to raise awareness of the ethical challenges posed by modern information and communication technologies (ICTs) amongst inhabitants of the Southern African region. It also seeks to equip students with the knowledge, understanding, and skills needed in their search for and use of information critical to their own and others' empowerment. The article describes the Model's theoretical and conceptual foundation and provides basic guidelines for applying the Model at undergraduate and graduate levels.
\end{abstract}


Keywords: INFORMATION ETHICS; CURRICULUM MODEL; SOUTHERN AFRICA; UNIVERSITY EDUCATION.

\section{Resumen}

Este trabajo propone el Modelo de Currículum en Ética de la Información, un modelo de educación heurística de nivel universitario, destinado a promover el uso favorable de información segura y responsable, en los escenarios multiculturales a través de África Austral. El Modelo es diseñado para crear conciencia sobre los desafíos éticos planteados por las modernas tecnologías de la información y la comunicación (TICs) entre los habitantes de la región del África austral. Se persigue también dotar a los estudiantes con el conocimiento, el entendimiento y las competencias necesarias para sus búsquedas y usos de información crítica, para sí y para el empoderamiento de otros. Este artículo describe los fundamentos teóricos y conceptuales del Modelo y proporciona orientaciones básicas para aplicar el modelo en los niveles universitarios de grado y posgrado.

Palabras clave: ÉTICA DE LA INFORMACIÓN; MODELO DE CURRICULUM; ÁFRICA AUSTRAL; EDUCACIÓN UNIVERSITARIA.

\section{Resumo}

Este artigo propõe o Modelo Curricular de Ética da Informação, um heurístico educacional de nível universitário destinado a promover a utilização segura, responsável e vantajosa da informação em contextos multiculturais em toda a África Austral. O Modelo foi concebido para sensibilizar os habitantes da região da África Austral para os desafios éticos colocados pelas modernas tecnologias de informação e comunicação (TIC). Procura também equipar os estudantes com os conhecimentos, compreensão e aptidões necessárias na sua busca e utilização de informação crítica para o seu próprio empoderamento e de outros. $\mathrm{O}$ artigo descreve os fundamentos teóricos e conceituais do Modelo e fornece orientações básicas para a aplicação do Modelo a nível de graduação e pós-graduação.

Palavras-chave: ÉTICA DA INFORMAÇÃO; MODELO CURRICULAR; ÁFRICA AUSTRAL; EDUCAÇÃO UNIVERSITÁRIA.

$\begin{array}{ll}\text { Received: } & 20 / 08 / 2020 \\ \text { Accepted: } & 02 / 05 / 2021\end{array}$

\section{Introduction}

Human use of information is typically affected by the extent to which individuals and groups regard information as trustworthy, credible, and true. In an age 
dominated by networked digital technology, information use is also affected by factors related to information access and ownership, as well as user ability to obtain and comprehend the information they need. These elements constitute the fundamentals of Information Ethics, which UNESCO grounds in the universal human rights of freedom of expression, access to information, and the right to education, privacy, and participation in cultural life (UNESCO, n.d.). To ensure the safe, responsible, and advantageous use of information, culturally responsive training is necessary at multiple levels of societal engagement. But what should such training entail at each of these levels? More specifically, what elements should an Information Ethics education program include, especially in a multicultural setting?

This paper proposes the Information Ethics Curriculum Model aimed at addressing this question in the context of university level education in Southern African countries. The Model is designed to raise awareness of the ethical challenges posed by modern information and communication technologies (ICTs) amongst inhabitants of the Southern African region. It also seeks to equip students with the knowledge, understanding, and skills needed in their search for and use of information critical to their own and others' empowerment. The following sections provide background on the Model's creation and the theoretical strands influencing the Model's development. As such, the Information Ethics Curriculum Model is discussed in both conceptual and practical terms, offering a general survey of the larger issues it seeks to address, as well as details on how the Model might be applied in specific educational settings.

\section{Background}

\subsection{Information Ethics Education in Southern Africa}

According to Douglass (2012), the study of Information Ethics education in Africa is relatively new, and although it had gained momentum in the decade preceding her article, it had not yet obtained sufficient empirical or normative footing. Using the 2010 Third International Information Ethics Conference for Africa as a starting point, Douglass (2012) noted the significant number of publications on Information Ethics education in the intervening years. For 
Douglass (2012), this activity suggested that the growing interest in Information Ethics education in Africa presented an opportunity, and possibly even a mandate, to take stock of methodological developments and implications for future work.

Douglass' (2012) claim about the lack of an empirical foundation for Information Ethics training reiterated Capurro's (2007) view that Information Ethics in Africa was a young academic field lacking formalized philosophical perspectives on the impact of ICTs on African societies and cultures. Since technology influences human relationships and reshapes institutions, economies, and moral values, Capurro (2007) rejects the idea that the adoption and application of technology is morally neutral. Capurro (2007) argues that ethical perspectives should guide the use of ICTs and that African citizens, leaders, and educational and research institutions should critically reflect on the changes facilitated by ICTs in their living environments and on ways of dealing with these changes over time.

In 2007, the University of Pretoria hosted the First Africa Information Ethics conference in conjunction with several international organizations. According to Capurro et al. (2007), the conference was inspired by the United Nations initiative on ICTs, the 2003 Geneva Declaration adopted by the World Summit on the Information Society (WSIS), and the implementation of Action Line C10 of the Geneva Plan of Action, all of which included a focus on global Information Ethics trends and the challenges these pose to inhabitants of the African continent. Conference participants acknowledged the growing impact of ICTs throughout Africa but conceded that the full range of opportunities enabled by the global information society has not been fully embraced or equitably realized (Capurro et al., 2007). To move in this direction, researchers, scholars, and students across academic disciplines must gain a fuller understanding of the ethical implications of ICTs on the broader African community (Capurro et al., 2007).

Although there appears to be consensus amongst stakeholders and organizations on the need for instructional curriculum on Information Ethics in Africa, adequate guidelines and standardization remain elusive. Furthermore, besides previous work at the University of Pretoria, hardly any research has been conducted on the content and delivery aspects of Information Ethics education at African universities, including the impact on students and teacher qualifications (Malan 
and Bester, 2014). The literature consulted in developing the model indicates the need for a thorough description of the content and structure of a standardized curriculum to effectively teach Information Ethics (Bester, 2018). The Information Ethics Curriculum Model proposed attempts to provide a heuristic for developing and designing Information Ethics education curricula that is applicable and relevant to the personal needs and broad policy frameworks of multicultural communities in Southern Africa. Ensuring safe, representative, and mediated information access and use contributes to the larger goal of promoting an ethical, empowered information society in this region (Malan and Bester, 2014).

\subsection{Theorizing the Information Ethics Curriculum Model}

The theoretical frame of reference informing the development and design of the curriculum model for teaching Information Ethics in Southern Africa is an eclectic one. Integrating various approaches to curriculum design, community development, and cultural diversity, the design process reflects Walker's (1971) naturalistic approach. In terms of curriculum development, Walker (1971) uses naturalistic to describe what he regards as an iterative five-step development process (see figure 1). The first step of Walker's (1971) model is the establishment of a "platform" from which subsequent deliberations on curriculum processes, procedures, and outcomes might emerge. According to Walker (1971), such a platform should include curriculum developers' perspectives on «what is», or the current status quo of education, and «what ought to be», or the possible and desirable future of education.

The "platform" for the design of a Southern African Information Ethics curriculum model was established over the course of two African Network for Information Ethics (ANIE) conferences: the first in Pretoria, South Africa in 2007, and the second in Gaborone, Botswana in 2010. Academics and policy makers from Africa, Europe, and the United States participated in these conferences, where potential curriculum designers, implementers, and recipients used the opportunity to state their positions on curriculum conceptualizations, theories, aims, processes, and procedures. Deliberating on and justifying their positions based on a combination of their own experiences and empirical data on 
the status quo («what is») of Information Ethics education, attendees managed to reach consensus on a platform with which the majority was comfortable (Bester, 2018).

Figure 1: Walker's naturalistic curriculum design model

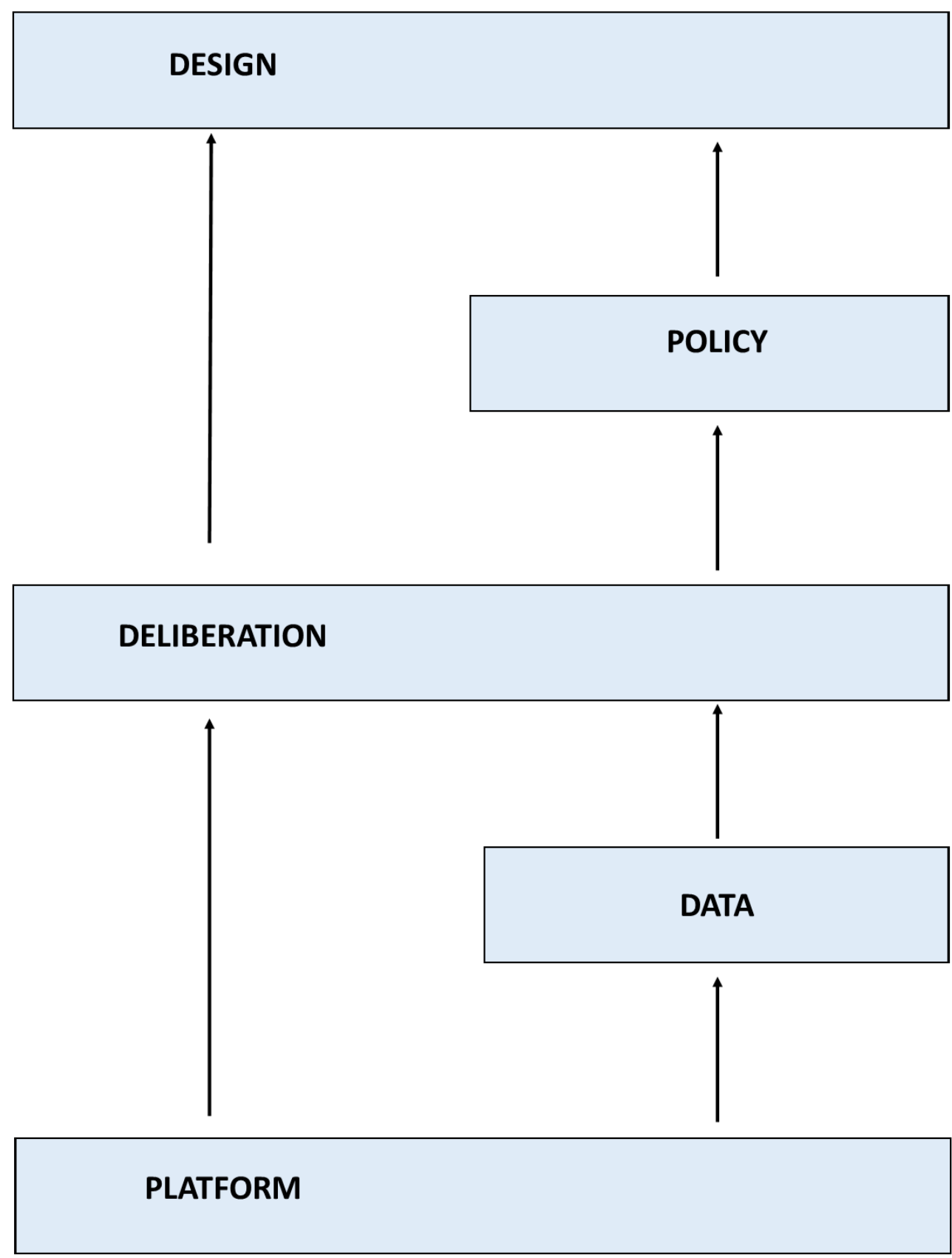

Source: Walker, D. F. (1971). A naturalistic model for curriculum development. School Review, $80(1), 51-58$. 
Delegates' consensus on "what ought to be» was encapsulated in the Tshwane Declaration on Information Ethics formulated at the 2007 conference. A vision of Africa as a mature and fully-fledged information and knowledge society is reflected in the declaration, one in which information technology is not used for personal gain only, but also as a means of strengthening Africa's global participation and competitiveness (Tshwane Declaration, 2007). The declaration was informed by the conviction that this vision could best be realized by enhancing rather than detracting from Africa's moral core-its values, beliefs, cultural traditions, and indigenous knowledge systems - and that doing so at the university level was a matter of urgency (Annual report, 2014). The declaration also reflected the delegates' agreement on the conceptual meaning of Information Ethics, the benefits Africa could derive from being a fully-fledged information and knowledge society, the opportunities associated with the responsible use of information technology, the need to create awareness around the impact of ICTs' presence and advances on the relationships between peoples and their world, and the potential contribution of a university program on Information Ethics to the realization of this vision (Tshwane Declaration, 2007).

The "platform" provided by these meetings served as the basis for further research on and the eventual design of the Information Ethics Curriculum Model proposed in this article. Three additional ANIE events were devoted to deliberations on the specific purpose, principles, structure, content, teaching, and learning approaches to be included in the curriculum framework (Bester, 2018). This process met what Walker (1971) described as authentic deliberation which «treats both ends and means... as mutually determining one another» (p. 52). In justifying their positions, conference delegates collected and presented relevant and tangential data, considered numerous solutions and their possible implications, and synthesized the various approaches and perspectives toward what the group determined was the right way to move forward (Bester, 2018; Walker, 1971).

\subsection{Conceptualizing the Information Ethics Curriculum Model}

In terms of traditional academic typologies, Information Ethics education could be viewed as an applied rather than a pure discipline. Given its purpose to produce 
graduates with the knowledge and skills to act as information ethics advocates in their own communities and places of employment, it might also be cast as a response to the challenges of the digital information age. Aimed at the development of students' contemplative and critical reasoning abilities (the domain of the pure disciplines), as well as their ability to solve problems associated with the misuse or abuse of ICTs (the domain of the applied disciplines), the Information Ethics Curriculum Model lends itself particularly well to cross-disciplinary knowledge acquisition (Bester, 2018). Conceptualized as a hierarchical two-tier structure (undergraduate and postgraduate), the Model is designed to foster knowledge and skills development on Information Ethics in ways that prioritize student «knowing, doing and being» (Barnett and Coate, 2004).

The development and design process for the Information Ethics Curriculum Model was characterized by intensive conference and workshop debates highlighting existing differences in institutional contexts, cultures, and operations, as well as differences between descriptive curriculum frameworks and prescriptive curricula. The consensus that emerged from this process recommends that the Model serve as a frame of reference for institutional curriculum developers to design their own institutionally-appropriate Information Ethics curricula, provided that these lend themselves to cross-curricular and disciplinary or subject specific teaching (Bester, 2018). To ensure that the academic standards of institutional curricula remain consistent, conference delegates recommended that the Model stipulate academic standards in the form of culminating learning outcomes which could serve as the basis for the formulation of institutionalspecific educational objectives (Bobbit, 1918; Spady, 1992; Spady, 1995; Tyler, 1949). The resulting «enabling outcomes» could then be used as the basis for institutional curriculum design - the selection of content, decisions on teachinglearning approaches, and the assessment criteria used to determine student competence-all of which should be «designed down» from the framework outcomes (Spady, 1992; Spady, 1995).

Acknowledging that this could generate institutional curricula which might differ markedly in content, teaching-learning approaches, and assessment 
procedures, the delegates were convinced that similar points of departure, outcomes, and design processes across institutions would help minimize any threat to the maintenance of common academic standards (Bester, 2018). While the prerogative to decide on the different curriculum elements or components rests with each adopting institution, delegates recommended including themes and topics deemed critical to the teaching and learning of Information Ethics and incorporating key principles to inform curriculum design decisions (Bester, 2018). They were adamant, though, that the inclusion of these in the Model should not be regarded as prescriptions but merely as suggestions or guidelines (Bester, 2018). As such, the devolution of curriculum design to the participating training institutions offering Information Ethics courses assumes that the potential gaps between the «actual curriculum» (the one taught in classrooms and lecture halls) and the «ideal curriculum» (the official paper version) is minimized because those responsible for its implementation are involved in its design (Malan, 2001). Furthermore, this early involvement is essential to curriculum designers knowing which content is most likely to interest their learners, which teaching approaches are most likely to facilitate learning, and which assessment procedures are most effective for determining student competence (Bester, 2018).

\subsection{Principles Informing the Design of the Curriculum Model}

The principles informing the design of the Information Ethics Curriculum Model represent a mix of operational and theoretical positions or views on the process and product of curriculum design. This included differences in institutional contexts, cultures, and principles derived from different theories on curriculum design - in particular, the design of higher education curricula. The result of this process is a flexible, two-tier outcomes-based curriculum structure that serves as a frame of reference for the design of institutionally appropriate Information Ethics curricula (Bester, 2018).

The use of outcomes as academic standards in the Model reflects classical product-oriented approaches to curriculum design (Bobbit, 1918; Gagne, 1967; Spady, 1992; Tyler, 1949). The inclusion of specific theories, themes, and topics as potential content reflects a modernist content-oriented position (Kelly, 1980). 
The models' emphasis on lecturers' and students' active interpersonal and content engagement reflects post-modernist praxis-oriented views on curriculum design and delivery (Doll, 1990; Barnett and Coate, 2004). Merging these positions into a descriptive curricular framework gives this Model the kind of flexibility needed in multicultural Southern African educational and community contexts. The Model's only prescription, apart from the culminating outcomes, is the requirement that curriculum content and teaching and learning activities reflect a mix of descriptive, emancipatory, and philosophical theories. This requirement helps ensure that the application of the Model provides a holistic and critical understanding of Information Ethics amongst university educators and students (Capurro, 2007).

The knowledge types and teaching-learning approaches described in the Model could be regarded as a compromise position. It reflects different academic views on the purpose of education in general, the role of higher education, the kinds of knowledge to be pursued, and the kinds of curriculum most suited to these. The foundational curriculum conferences and workshops featured debate on these points and on the merits of pure versus applied disciplines (Bester, 2018). On the one hand, some claimed that new knowledge is generated only through the study of pure disciplines that focus on and gain value from the pursuit of knowledge as an end in and of itself. On the other hand, some claimed that the pursuit of knowledge is of value only when it is relevant; that is, if it is pursued as a means towards an end, which is the purpose of applied disciplines (Bester, 2018; Muller, 2000).

The discussion was further informed by diverging views on the reasons for the pursuit of different knowledge types at different points in time. For example, Musson (2006) argues that knowledge is a social construct and claims that differences can be ascribed to the values and interests of the historical and social contexts in which the knowledge type is produced or pursued. Regarding knowledge types that would be of most value in the Information Age, Drucker (1993) argues that the production of knowledge workers and information practitioners is the key to social and economic development, as well as the solutions to complex and unpredictable problems. The primary purpose of 
education should therefore not be the acquisition of knowledge per se, but the nurturing of particular types of human beings (Barnett and Coate, 2004).

Higher education should aim to equip students not only with knowledge, skills, and values - thus imbuing qualities only accidentally and infrequently relevant to dealing with problems and conflicts in the Information Age-but to develop their capacity for knowing, doing, being, and self-understanding (Barnett and Coate, 2004). According to Musson (2006), changes in the value attached to particular knowledge types also changes the ways identified values are codified. Since access to information is relatively unrestricted and uninterrupted in this digitally dominated era, knowledge must be codified in ways that create opportunities for interdisciplinary and cross-disciplinary studies and, by implication, for new ways of teaching and learning (Muller, 2008). In this regard, transgressing or breaking down disciplinary boundaries might be a matter of epistemic morality (Boghossian, 2007; Muller, 2000). The Information Ethics Curriculum Model described in the following section attempts to do exactly that.

\section{The Information Ethics Curriculum Model}

The Information Ethics Curriculum Model is designed to contribute to the development of undergraduate and postgraduate students' knowing, doing, and being in relation to Information Ethics. Specific applications of the model can be determined by the nature and purpose of the academic field employing it and staggered to align with the appropriate education level. The emphasis at Undergraduate level is on Information Ethics issues and challenges related to the academic field of study, while the emphasis at Postgraduate level is on Information Ethics research, (Bester, 2018).

\subsection{Undergraduate Information Ethics Education}

The Undergraduate Information Ethics teaching and learning component of the Model consists of five outcomes-based units. The unit outcomes attempt to answer Information Ethics questions specific to the unit concerned. As such the outcomes serve as the basis for the selection of recommended unit content and teaching-learning resources, as well as for decisions on teaching-learning 
approaches and student competence. Unit 1 is the foundational unit and should be offered first, while the other units could be offered in any sequence either as part of a cross-disciplinary program or as stand-alone units. Alternatively, given the thematic nature of the issues they deal with, they could all be deconstructed, reconstructed, or combined in ways that facilitate the integration of relevant thematic content and/or perspectives into existing academic programs across disciplinary boundaries (Bester, 2018). What follows is a brief description of the content, learning outcomes, and activities of each of these units.

\subsubsection{Foundations of Information Ethics (Unit 1)}

As an orientation unit, the primary outcome for those completing it is to gain a basic understanding of Information Ethics - its conceptualisation, underpinning principles, advocacy rationale, and potential impact on users' digital behaviour. To this purpose, students and lecturers are urged to use their own personal experiences with digital technologies-ICTs in particular-as well as media articles and reports as primary teaching-learning resources and complementing these with academic journal content when appropriate. Using these sources as the basis, students analyse, compare, and evaluate the ways in which concepts and information types and sources are defined, discuss different information issues and challenges (their own and those reported in the media) in terms of their potential impact on users' lives and on-line behaviour. Furthermore, students read journal articles on Information Ethics and its related theories and consider the possible consequences of information abuse or misuse in different contexts, and the tensions between and impact of global Information Ethics on Southern Africa's multi-cultural value systems (Bester, 2018).

\subsubsection{Information Ethics Philosophy (Unit 2)}

Given the philosophical motivation of this unit, students are tasked with developing a personal moral base around decisions and choices in accessing, using, and disseminating digital information. This includes developing a critical understanding of the ways in which the misuse of information and ICTs undermine basic human rights and applying their critical thinking and reasoning skills in the analysis and resolution of Information Ethics issues and challenges. 
To this purpose, the Model recommends the study of an eclectic mix of philosophies (past and present, European and Africa) with a view to students constructing their own philosophical arguments around more general principles. Students are encouraged to engage in philosophical debates on the value and impact of Information Ethics on human behaviour in general and on the value systems of multicultural societies like Southern Africa in particular. The Model recommends the use of academic texts on different relevant philosophies, coupled with case studies illustrating a range of philosophical and Information Ethics dilemmas (Bester, 2018).

\subsubsection{Information Ethics and the Law (Unit 3)}

In the unit on Information Ethics and the law, students gain knowledge of their own country's information and media laws and the potential consequences when these laws are breached. In the process students develop critical awareness of citizens' rights and responsibilities regarding information and information communications technology, as well as the potential tensions and conflicts between cultural, legal, and philosophical perspectives on information rights and responsibilities. Content covered in this unit includes international and regional laws as well as universal and local regulations and prescripts on human rights, specifically those related to information access, use, misuse and abuse (Bester, 2018). These outcomes assume some student familiarity with the philosophical foundations of Information Ethics, but if this background is lacking the relevant units can be completed concurrently, or content from the philosophy unit related to legal matters could be extracted and incorporated into this unit. What is of critical importance is that students become familiar with the way information legislation in their own countries - media laws in particular-sometimes restricts, undermines, or violates individuals' or groups' information and human rights. To this purpose, the analysis of relevant court cases is also recommended (Bester, 2018).

\subsubsection{Information Ethics in the Southern African Context (Unit 4)}

This unit focuses on critical discussions on Information Ethics across Africa and in the Southern African region. The content highlights the development of a 
continent-wide information and knowledge society and emphasizes students' role helping to address the challenges attending this process. Students gain awareness of the tensions between global and African perspectives on the ethics of information as well as the ways in which multi-cultural knowledge and value systems promote or hinder the development of ethically responsible information and knowledge societies in different African countries (Bester, 2018). It includes analysis and critical discussions of statistics, media reports, and case studies reflecting different tiers of knowledge and information in any specific country and time, along with comparison and critical reflection on the impact of different value systems on a country's development as an ethical yet globally competitive information and knowledge society (Bester, 2018).

\subsubsection{Virtual Information Ethics (Unit 5)}

In practice, Unit 5 should in fact be considered and facilitated as a virtual unit, one in which the content, teaching-learning approaches, and study materials will differ from context to context. What is important with regard to this unit is that its inclusion as a theme or sub-unit in academic programs should develop in students the knowing, doing, and being which, according to Barnett and Coate (2004), should be the key outcome of higher education studies. Students are given the opportunity to practically manifest their Information Ethics knowing, doing, and being in virtual academic activities across the curriculum, including course assignments and other school or work contexts requiring the access, use, manipulation, and dissemination of digital information. In doing so, students' online behavior displays their willingness and commitment to use information and ICTs in a culturally aware, morally responsible, and accountable manner. Student participation and actions should reflect a commitment to act as Information Ethics change agents who, by sharing their own knowledge, understanding, and skills with others in their sphere of influence contribute to the development of ethically responsible Southern African information and knowledge societies (Bester, 2018).

\subsection{Postgraduate Information Ethics Education}

Assuming postgraduate students are interested in finding solutions to Information

Ethics dilemmas and challenges, the emphasis at this tier of the Model is on the 
development of Information Ethics research methods and approaches. The scope and depth of these teachings are determined by the nature and purpose of the postgraduate degree and the relevant academic field of study. Postgraduate research programs might incorporate the Model into coursework, guided research, independent research, or any combination of program components. The Model creates an opportunity for detailed development of postgraduate programs in academic fields for students who may not have been exposed as undergraduates to any Information Ethics education. Themes or topics relevant to the academic field concerned could be explored in greater depth, either from the angle of the discipline concerned or from a multi-disciplinary perspective, resulting in a merging of Information Ethics and domain-specific research frameworks (Bester, 2018).

\section{Conclusion}

As indicated, the only prescriptions in the Model are the outcomes; content, resources, methodologies, and assessment procedures included in the Model are recommendations due to the relative newness of Information Ethics as a field of study. The content suggested in the Model represents a mix of descriptive, emancipatory and philosophical theories which, in conjunction with the suggested teaching-learning resources and activities, lend themselves to the acquisition of students' conceptual, contextual, and procedural knowledge and skills. Suggestions on student competency evaluation reflect the outcomes-based principle that recommends utilizing summative and formative assessment methods for teaching-learning activities (Spady, 1995). The naturalistic design of the Model emerged from a consensual platform of values or beliefs about what exists and what is possible, the collection and presentation of data to validate positions and justify design decisions, and the adoption of the most defensible course of action subject to acknowledged constraints (Bester, 2018; Walker, 1971).

The Information Ethics Curriculum Model presents higher education institutions in the Southern African region with the opportunity to reconsider traditional ways of coding and disseminating knowledge, where educators are less concerned about the maintenance of rigid disciplinary boundaries and more focused on student 
development. This does not mean that they should discard disciplinary knowledge or procedures entirely, but that these should be taught and learned in ways that reflect responsiveness to the demands and challenges of a digitally dominated and multicultural Information Age. In this context, it is imperative that academic programs across the region include at least some Information Ethics training. Whether this is in the form of short courses or stand-alone units, by integrating Information Ethics themes into current programmes or developing it as an applied discipline in its own right, the Model provides a framework on which to base their efforts.

\section{Bibliography}

African Centre of Excellence for Information Ethics. Annual report: 1 January 2014 - 31 December 2014. (2014). African Centre of Excellence for Information Ethics, University of Pretoria. Retrieved from https://www.up.ac.za/african-centre-of-excellence-for-informationethics/article/2460908/annual-reports

ANIE. (2007). Tshwane declaration on Information Ethics in Africa. Adopted on 7 February 2007 at Africa Information Ethics Conference. Pretoria. RSA. Africa Network for Information Ethics.

Barnett, R., \& Coate, K. (2004). Engaging the curriculum in higher education. Maidenhead, UK: Open University Press.

Bell, D. (1980). Sociological journeys essays 1960-1980. London, UK: Heinemann.

Bester, B. C. (2018). Development of a framework for teaching Information Ethics to various communities in Southern Africa (Unpublished doctoral dissertation). University of Pretoria, Pretoria, RSA.

Bobbit, F. (1918). The Curriculum. Cambridge, UK: The Riverside.

Boghossian, P. (2006). Fear of knowledge: Against relativism and constructivism. Oxford, UK: Oxford University Press.

Capurro, R. (2007). Information Ethics for and from Africa. International Review of Information Ethics, 55, 1-13. 
Capurro, R., Britz, J. J., Bothma, T. J. D., \& Bester, B. C. (Eds.). (2007). African reader on Information Ethics. Pretoria, South Africa: African Centre of Excellence for Information Ethics.

Doll Jr., W. E. (1993). A post-modern perspective on curriculum. New York, NY: Teachers College Press.

Douglass, K. (2012). A framework for understanding the teaching of Information Ethics in Africa. Libri, 62, 19-40.

Drucker, P. F. (1993). Post-capitalist society. New York, NY: HarperBusiness.

Gagne, R. M. (1967). Curriculum research and the promotion of learning. In R. E. Stake (Ed.), Perspectives of curriculum evaluation (pp. 19-38). Chicago, IL: Rand McNally \& Company.

Kelly, A. V. (1989). The curriculum: Theory and practice (3rd ed.). London, UK: Paul Chapman Educational Publishing.

Malan, B. (2001). Curriculum 2005: Transformation and outcomes-based education (Unpublished doctoral dissertation). Rand Afrikaans University, Johannesburg, RSA.

Malan, B., Bester, C. (2014). Curriculum to teach Information Ethics at universities in Africa. Pretoria, South Africa: African Centre of Excellence for Information Ethics.

Muller, J. (2000). Reclaiming knowledge: Social theory, curriculum and education policy. London, UK: RoutledgeFalmer.

Musson, D. (2007). The production of Mode 2 Knowledge in higher education in South Africa.

Retrieved from Proquest Dissertations \& Theses Global. (Order No. 0818627)

Spady, W. G. (1992). It's time to take a closer look at outcomes-based education. Outcomes 11(2), 6-13.

Spady, W. G. (1995). Outcomes-based education: Critical issues. Alexandria, VA: American Association of School Administrators.

Tshwane Declaration on Information Ethics in Africa. (2007). African Network for Information Ethics, University of Pretoria. Retrieved from https://www.up.ac.za/african-centre-of-excellence-for-informationethics/article/2616104/tshwane-declaration 
Tyler, R. W. (1949). Basic principles of curriculum and instruction. Chicago, IL: University of Chicago Press.

United Nations Educational, Scientific, and Cultural Organization. (n.d.).

Information Ethics. Retrieved from

https://en.unesco.org/themes/information-ethics

Walker, D. F. (1971). A naturalistic model for curriculum development. School Review, 80(1), 51-58.

\section{Author contribution}

The authors of this manuscript prepared the entirety of it in equal parts.

\section{Editor's notes}

The editor responsible for the publication of this article was Rafael Capurro.

Style editing and linguistic revision to the wording in this text has been performed by Prof. Adj. Hugo E. Valanzano (State University, Uruguay).

Nilzete Ferreira Gomes (Universidade Federal Rural da Amazõnia (UFRA), Pará, Brazil), was in charge of translating from Portuguese to Spanish. 